\title{
LONG-TERM TRENDS OF TROPOSPHERIC OZONE IN THE CZECH REPUBLIC, 1993-2018
}

\author{
MILAN VANA \& JAROSLAV PEKAREK \\ Czech Hydrometeorological Institute, Košetice Observatory, Czech Republic
}

\begin{abstract}
The regular measurement of tropospheric ozone in the Czech Republic began within the National Air Pollution Monitoring Network operated by the Czech Hydrometeorological Institute in 1993. The longterm trend study is based on the data from the stations with the longest homogeneous data series: Košetice (EMEP, GAW, and ACTRIS) and Svratouch (EMEP), Praha-Libuš (suburban area of the capital Prague) and Churáňov (mountain site). Non-parametric Mann-Kendall method was used for trend evaluation. Slightly decreasing trends in mean annual concentrations were found at mountain and background level in the whole period as well as in the first part (1993-2005). After 2006 no trend was found. The warm period (April-September) displays similar patterns as the whole year at regional and mountain level. In contrast, no trend was found in the whole period at EMEP stations and slightly decreasing tendency at mountain stations in the cold period. The suburban level is characterized by a slightly increasing trend. The difference between mean annual concentrations at regional and suburban stations was smaller in last years. The annual variation is characterized by maxima at the end of spring. According to the current EU air quality legislation, the target value for protection of human health is exceeded when the 8-hour running mean is higher than $120 \mu \mathrm{g} . \mathrm{m}^{-3} 25$ times on average for 3 years. The limit was exceeded at all stations during the period 1993-2005, but at the same time significant drop of high ozone episodes was found. After 2006, the 3-year mean fluctuated around the target limit at all stations. Assessment of the ozone impacts on ecosystems using the AOT40 index suggests that the critical level was exceeded for long periods, not only in the regional areas but almost over the whole of the Czech Republic. In the last decade, the values varied round the requested limit.

Keywords: tropospheric ozone, long-term trends, critical levels, background scale, Czech Republic.
\end{abstract}

\section{INTRODUCTION}

Tropospheric ozone does not have a source in the atmosphere. This is a secondary substance formed by a number of complicated nonlinear photochemical reactions, which were described in detail, e.g. in [1]. Tropospheric ozone precursors include nitrogen oxides $\left(\mathrm{NO}_{\mathrm{x}}\right)$ and non-methane volatile organic compounds (NMVOC), while methane $\left(\mathrm{CH}_{4}\right)$ and carbon monoxide $(\mathrm{CO})$ play a role on a background scale. The photolysis of $\mathrm{NO}_{2}$ by radiation with a wavelength of $280-430 \mathrm{~nm}$ is an important reaction, forming $\mathrm{NO}$ and atomic oxygen. Ozone molecules are formed by the reaction of atomic and molecular oxygen in the presence of a catalyst. Simultaneously, ozone is titrated with nitrogen oxide, NO, with the formation of $\mathrm{NO}_{2}$ and $\mathrm{O}_{2}$. If ozone is replaced by radicals in this reaction, its concentration increases in the atmosphere. The $\mathrm{OH}$ radical plays an especially important role in this reaction.

In the formation of tropospheric ozone from precursors, the absolute amounts of precursors is not important, but rather their mutual ratios [2], [3]. In areas where the regime is limited by $\mathrm{NO}_{\mathrm{x}}$, characterized by relatively low concentrations of $\mathrm{NO}_{\mathrm{x}}$ and high concentrations of VOC, the ozone concentrations increase with increasing $\mathrm{NO}_{\mathrm{x}}$ concentrations, but only minimally with increasing VOC concentrations. On the other hand, in areas with a regime limited by VOC, the ozone concentrations decrease with increasing $\mathrm{NO}_{\mathrm{x}}$ concentrations and the ozone concentrations increase with increasing VOC concentrations. Areas with a high $\mathrm{NO}_{\mathrm{x}} / \mathrm{VOC}$ ratio are typically polluted areas around the centers of large cities. The dependence of ozone formation on the initial concentrations of 
VOC and $\mathrm{NO}_{\mathrm{x}}$ is frequently expressed by ozone isopleth diagrams, which depict the maximum attained ozone concentration as a function of the initial $\mathrm{NO}_{\mathrm{x}}$ and VOC concentrations [4]. Not only the concentrations of precursors, but also meteorological conditions, play an important role in the ozone formation [5]. The ozone concentrations increase with increasing ultraviolet radiation and temperature, but decrease with increasing relative atmospheric humidity. High concentrations are often connected with prolonged anticyclone situations. In addition to the above-described photochemical mechanisms, the concentrations of ozone can also increase in episodes as a result of penetration of stratospheric ozone into the troposphere and also during thunderstorms. Recently, there has also been an increase in the importance of long-range transmission of ozone in the air streams in the northern hemisphere to Europe and North America from source areas in south-east Asia. Tropospheric ozone is removed from the atmosphere by reaction with NO and dry deposition. Ozone can be transported in the troposphere over long distances, accumulate and reach concentrations far from its place of origin [6].

$\mathrm{NO}_{\mathrm{x}}$ are formed in all combustion processes. NMVOC are emitted from a number of anthropogenic sources (transport, manipulation with petroleum and its derivatives, refineries, the use of coatings and solvents, etc.), and also natural sources (e.g. biogenic emissions from vegetation). In the Czech Republic, NOx emissions dropped by 80\% in the period 1990-2016 and by $55 \%$ after 2000 . The total $\mathrm{NO}_{\mathrm{x}}$ emissions are negatively affected by a considerable increase in emissions from mobile sources. The share of $\mathrm{NO}_{\mathrm{x}}$ emissions from mobile sources increased from $27.0 \%$ in 1990 to $55 \%$ by nowadays. In the whole European Union (EU), NOx emissions dropped EU by 58\% between 1990 and 2016 and by $42 \%$ after the year 2000 . The VOCs emissions in the Czech Republic dropped by 63\% in the period 1990-2016 and $30 \%$ after 2000 . The figures for the whole of the EU were $62 \%$ in $1990-2016$ and $40 \%$ after 2000 [7].

The main effect of ozone on the human organisms is irritative. It irritates the conjunctiva, nasal mucous membranes and bronchi. Short-term studies show that ozone concentrations may have adverse effects on pulmonary function leading to lung inflammation and respiratory problems [8]. Higher concentrations cause irritation-induced narrowing of the respiratory tract and breathlessness. More sensitive to ozone are people with chronic obstructive diseases of the lungs and asthma patients. Higher concentrations of ozone are purportedly associated with increased mortality during the day. Tropospheric ozone damages vegetation, impairs plant growth and decreases crop yields; it can damage forest ecosystems and reduce biodiversity [8].

Measurement of tropospheric ozone concentrations, in view of its key role in chemical and physical processes in the troposphere, is one of the compulsory parts of international air quality monitoring programmes at regional level. In the Czech Republic, the measurements began within the CHMI's Automatic Monitoring of Ambient Air Pollution network in 1993. This study is based on the data from the stations with longest data series: Košetice and Svratouch are the background stations, involved in EMEP programme, Praha-Libuš represents the suburban area of the capital Prague and Churánov is a typical mountain site [9]. The geographical co-ordinates of the stations are indicated in Table 1. The objective of the study is to evaluate the trends of tropospheric ozone concentrations at the regional scale in the Czech Republic in the period 1993-2018. The period under review was divided into two identical sub-periods 1993-2005 and 2006-2018. The motivation for dividing of the whole period was an effort towards better understanding of influence of environmental measures for reduction of ozone precursor's emission as well as the changing climatological conditions. The similar approach was used also in pan-European assessment [12]. 
Table 1: Geographical co-ordinates of selected stations.

\begin{tabular}{|l|c|c|c|}
\hline & Altitude (m a.s.l.) & Longitude & Latitude \\
\hline Košetice & $534 \mathrm{~m}$ & $49^{\circ} 35^{\prime} \mathrm{N}$ & $15^{\circ} 05^{\prime} \mathrm{E}$ \\
\hline Praha-Libuš & $301 \mathrm{~m}$ & $50^{\circ} 00^{\prime} \mathrm{N}$ & $14^{\circ} 27^{\prime} \mathrm{E}$ \\
\hline Svratouch & $737 \mathrm{~m}$ & $49^{\circ} 73^{\prime} \mathrm{N}$ & $16^{\circ} 03^{\prime} \mathrm{E}$ \\
\hline Churáňov & $1,118 \mathrm{~m}$ & $49^{\circ} 04^{\prime} \mathrm{N}$ & $13^{\circ} 37^{\prime} \mathrm{E}$ \\
\hline
\end{tabular}

The nonparametric Mann-Kendall method [10] was used for statistical evaluation of tropospheric ozone trends significance. This test divides the trend significance to four categories:

$\begin{array}{ll}* * * & \text { if trend at } \alpha=0,001 \text { level of significance; } \\ * * & \text { if trend at } \alpha=0,01 \text { level of significance; } \\ * & \text { if trend at } \alpha=0,5 \text { level of significance; } \\ + & \text { if trend at } \alpha=0,1 \text { level of significance. }\end{array}$

Test $Z$ characterize the existence and significance of the trend. A positive (negative) value of Z indicates an upward (downward) trend. Sen's slope estimate Q represents estimator for true slope of the trend per year.

\section{TREND OF TROPOSPHERIC OZONE CONCENTRATIONS}

Fig. 1 shows general tendency of mean annual ozone concentrations at selected stations, while the trends in warm (April-September) and cold (October-March) periods are specified in Figs 2 and 3. The results of trend analysis are shown in Table 2. and the mean annual concentrations in Table 3.

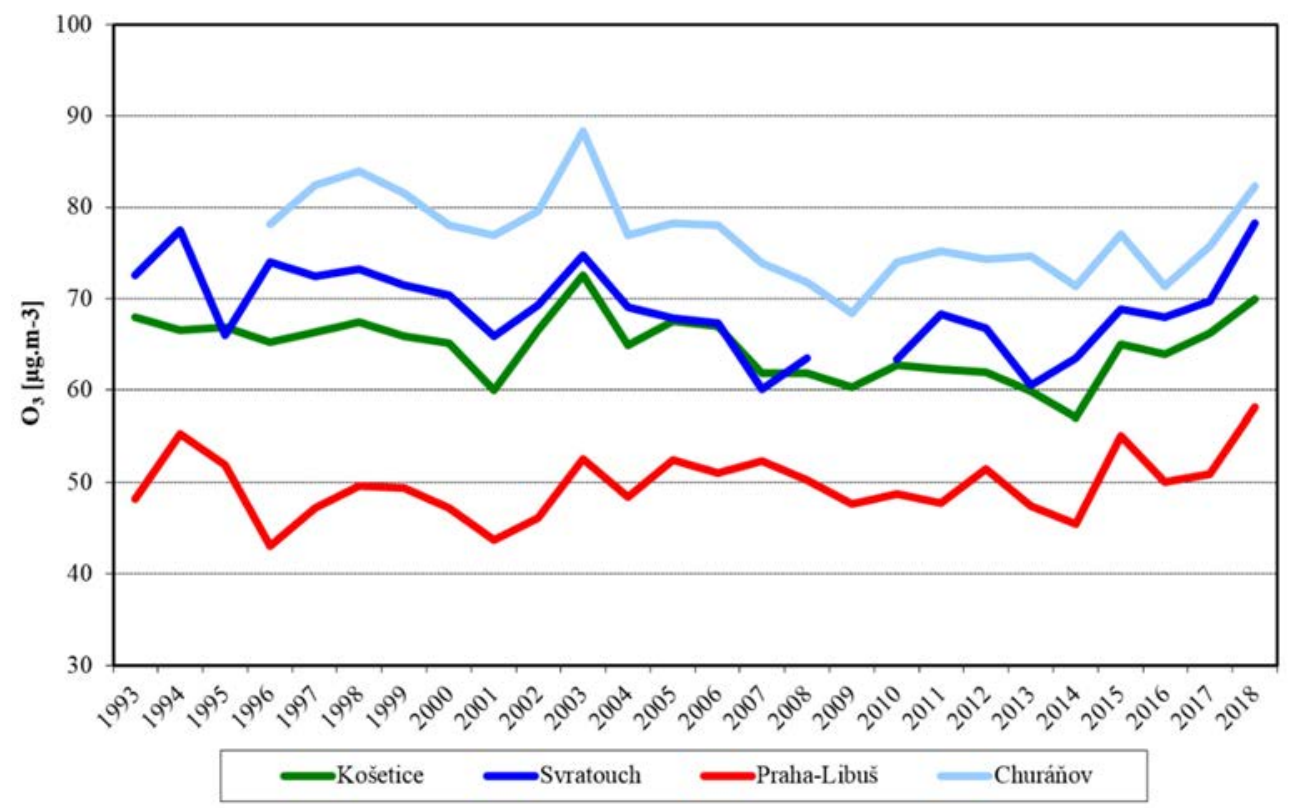

Figure 1: Mean annual tropospheric ozone concentrations at stations Košetice, Svratouch, Praha-Libuš, Churáňov (1993-2018). 


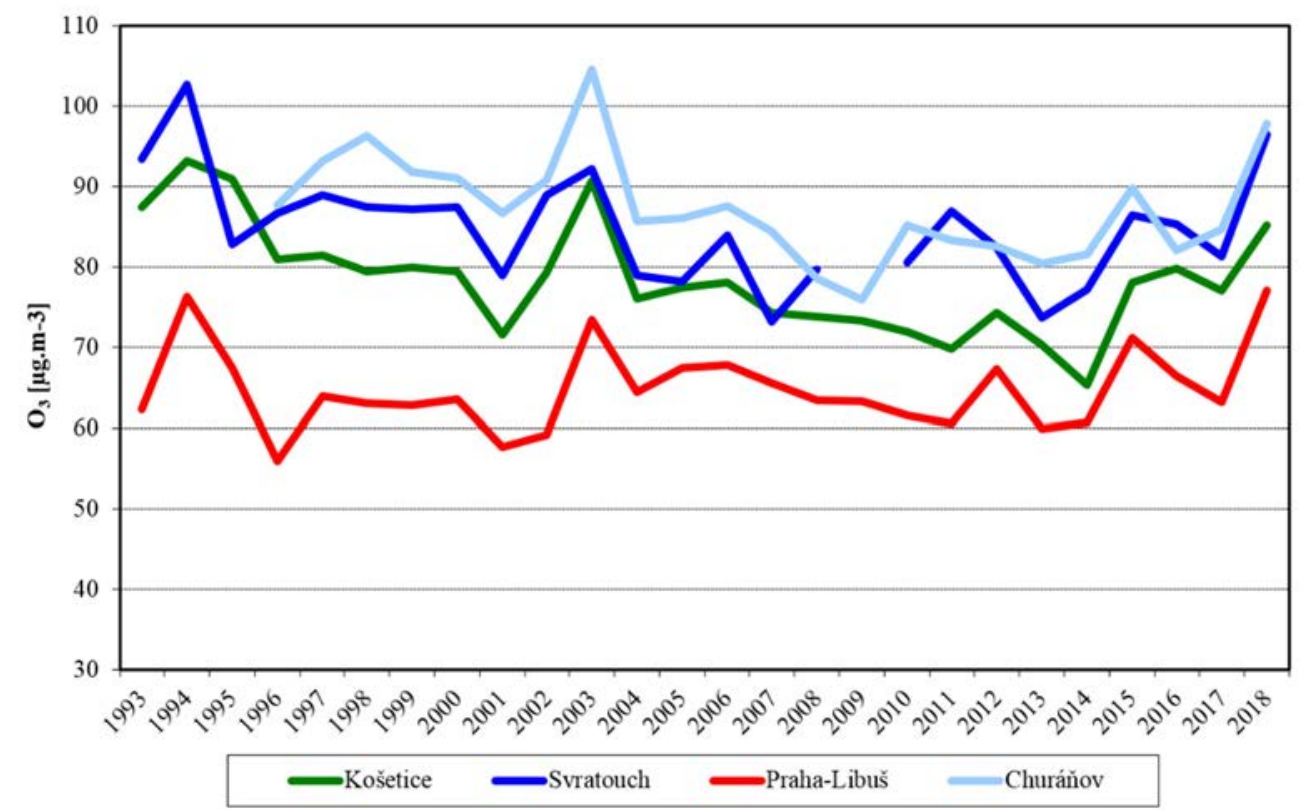

Figure 2: Mean annual tropospheric ozone concentrations in the warm period at stations Košetice, Svratouch, Praha-Libuš, Churáňov (1993-2018).

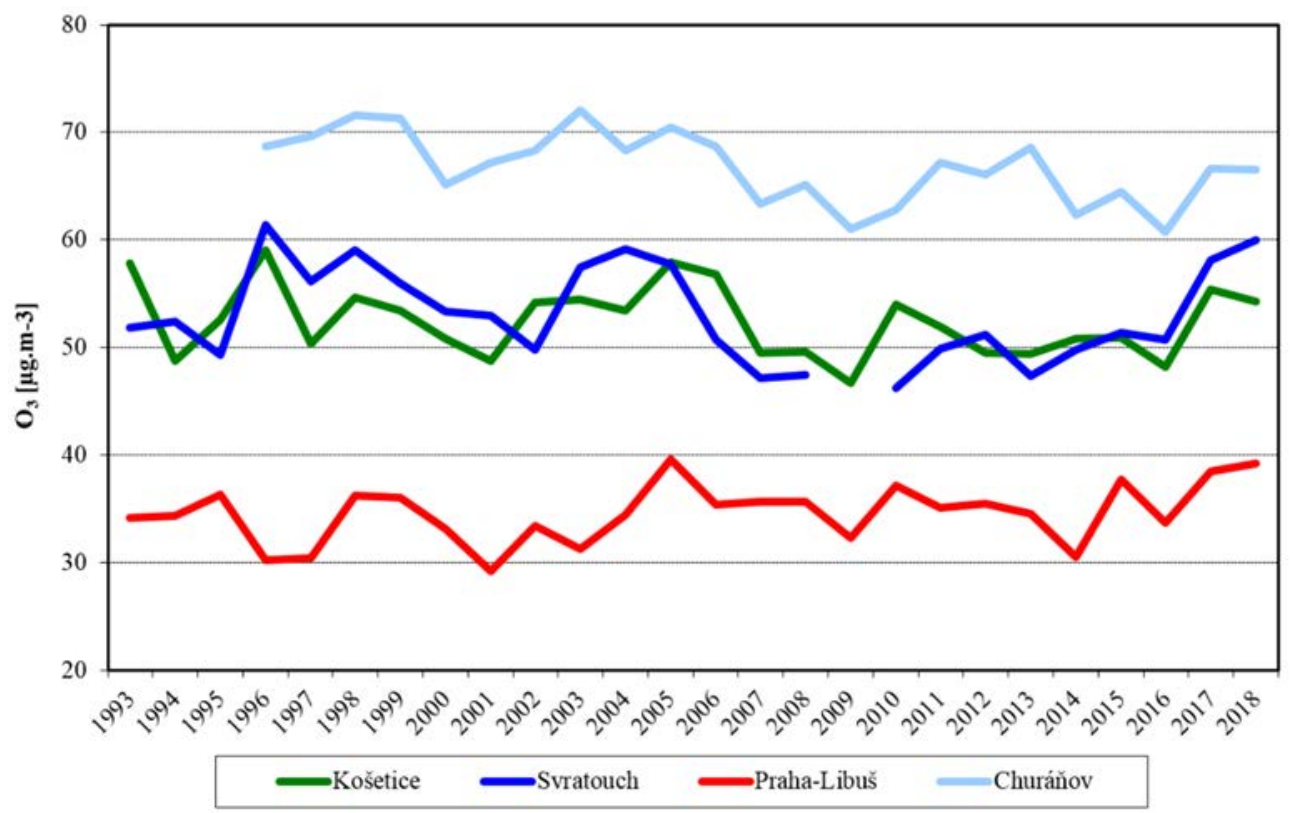

Figure 3: Mean annual tropospheric ozone concentrations in the cold period at stations Košetice, Svratouch, Praha-Libuš, Churáňov (1993-2018). 
Table 2: Trend analysis of tropospheric ozone trends from the Czech stations Košetice, Svratouch, Churáňov and Libuš.

\begin{tabular}{|c|c|c|c|c|c|c|c|c|c|c|c|c|}
\hline \multirow[b]{2}{*}{ Period } & \multicolumn{3}{|c|}{ Košetice } & \multicolumn{3}{|c|}{ Svratouch } & \multicolumn{3}{|c|}{ Churáňov } & \multicolumn{3}{|c|}{ Libuš } \\
\hline & $\mathrm{Q}$ & $\mathrm{Z}$ & Sig. & $\mathrm{Q}$ & $\mathrm{Z}$ & Sig. & $\mathrm{Q}$ & $\mathrm{Z}$ & Sig. & $\mathrm{Q}$ & $\mathrm{Z}$ & Sig. \\
\hline \multicolumn{13}{|l|}{ Whole } \\
\hline 1993-2018 & -0.2 & -2.1 & $*$ & -0.4 & -2.3 & $*$ & -0.4 & -2.2 & $*$ & 0.1 & 1.1 & \\
\hline 1993-2005 & -0.2 & -0.8 & & -0.7 & -2.3 & $*$ & -0.3 & -0.5 & & 0.0 & 0.0 & \\
\hline 2006-2018 & 0.5 & 1.4 & & 0.9 & 2.1 & $*$ & 0.2 & 0.8 & & 0.1 & 0.3 & \\
\hline \multicolumn{13}{|l|}{ Warm } \\
\hline 1993-2018 & -0.6 & -3.2 & $* *$ & -0.4 & -1.9 & + & -0.4 & -2.4 & $*$ & 0.1 & 0.6 & \\
\hline 1993-2005 & -0.8 & -2.6 & $* *$ & -1.0 & -1.5 & & -0.5 & -1.3 & & 0.0 & 0.1 & \\
\hline 2006-2018 & 0.3 & 0.6 & & 0.9 & 1.5 & & 0.3 & 0.4 & & 0.0 & 0.0 & \\
\hline \multicolumn{13}{|l|}{ Cold } \\
\hline 1993-2018 & -0.1 & -0.9 & & -0.1 & -0.3 & & -0.3 & -2.5 & $*$ & 0.1 & 1.6 & \\
\hline 1993-2005 & 0.2 & 0.6 & & 0.5 & 1.3 & & 0.1 & 0.2 & & 0.1 & 0.2 & \\
\hline 2006-2018 & 0.1 & 0.3 & & 0.9 & 2.8 & $* *$ & -0.1 & -0.2 & & 0.2 & 0.4 & \\
\hline
\end{tabular}

Table 3: Mean annual tropospheric ozone concentrations at the Czech stations Košetice, Svratouch, Churáňov and Libuš $\left(\mu \mathrm{g} \cdot \mathrm{m}^{-3}\right)$.

\begin{tabular}{|l|c|c|c|c|}
\hline & Košetice & Svratouch & Churáňov & Libuš \\
\hline Whole period \\
\hline $1993-2018$ & 64.6 & 68.2 & 77.8 & 49.7 \\
\hline $1993-2005$ & 66.4 & 71.3 & 80.4 & 48.8 \\
\hline 2006-2018 & 62.8 & 65.1 & 75.7 & 50.6 \\
\hline Warm period \\
\hline 1993-2018 & 78.4 & 84.1 & 88.0 & 64.9 \\
\hline $1993-2005$ & 82.1 & 87.4 & 91.4 & 64.3 \\
\hline 2006-2018 & 74.7 & 80.7 & 85.4 & 65.5 \\
\hline Cold period & 52.4 & 51.9 & 67.5 & 34.7 \\
\hline 1993-2018 & 53.5 & 54.6 & 69.2 & 33.8 \\
\hline $1993-2005$ & 51.3 & 49.2 & 66.1 & 35.6 \\
\hline $2006-2018$ &
\end{tabular}

Slightly significant downward trend was found at background stations and the mountain station in the whole period under review as well as in the first period 1993-2005. On contrary, after 2005, no trend was found, the mean annual concentrations displayed upward tendency. An exception was the year 2003 with extremely hot summer, when the concentrations were the highest in the whole period under review. Long-term average values at EMEP stations Kosetice $\left(65 \mu \mathrm{g} \cdot \mathrm{m}^{-3}\right)$ and Svratouch $\left(68 \mu \mathrm{g} \cdot \mathrm{m}^{-3}\right)$ belong together with similarly located German and Austrian stations among the highest in the whole EMEP network [11]. Most stations of EMEP network reported a downward trend, however, because of the large interannual variability of ozone, the downward trends are statistically significant at only $30-50 \%$ of the sites [12]. 
Warm period displays similar patterns as the whole year at background and mountain scale. The situation in the cold period is quite different. No trend was found in the whole period at background stations and slightly decreasing tendency at mountain station In the period 2006-2018, increasing trend was found (at Svratouch even statistically significant). The difference between the mountain site and background level was visibly higher in the cold period. Suburban station is characterized by slightly increasing tendency, which is not statistically significant. The difference between mean annual concentrations at background and suburban stations was smaller during the period under review from $20 \mu \mathrm{g} . \mathrm{m}^{-3}$ in the 90 to $12 \mu \mathrm{g} . \mathrm{m}^{-3}$ in last five years.

Tropospheric ozone concentrations in the Czech Republic have a marked annual variation with maxima at the end of spring (Fig. 4). In June and sometimes also in July there is a decrease caused by the onset of the so-called "continental monsoon", which brings increased cloud cover and a drop in solar radiation. We then register a second maximum in July and August (especially in very hot summers). In the very cool year 1996 we recorded a maximum concentration as early as April. Concentrations at mountain station are higher all year round. The annual variation of tropospheric ozone concentrations at the background stations is comparable with similarly located Central European EMEP stations. EMEP Assessment report [12] indicates an increase in winter and springtime mean ozone in EMEP domain, which is generally attributed to changes in baseline ozone (both intercontinental transport and stratosphere-troposphere exchange) and also local effects such as the longer lifetime of ozone because of reduced availability of NO (reduced titration).

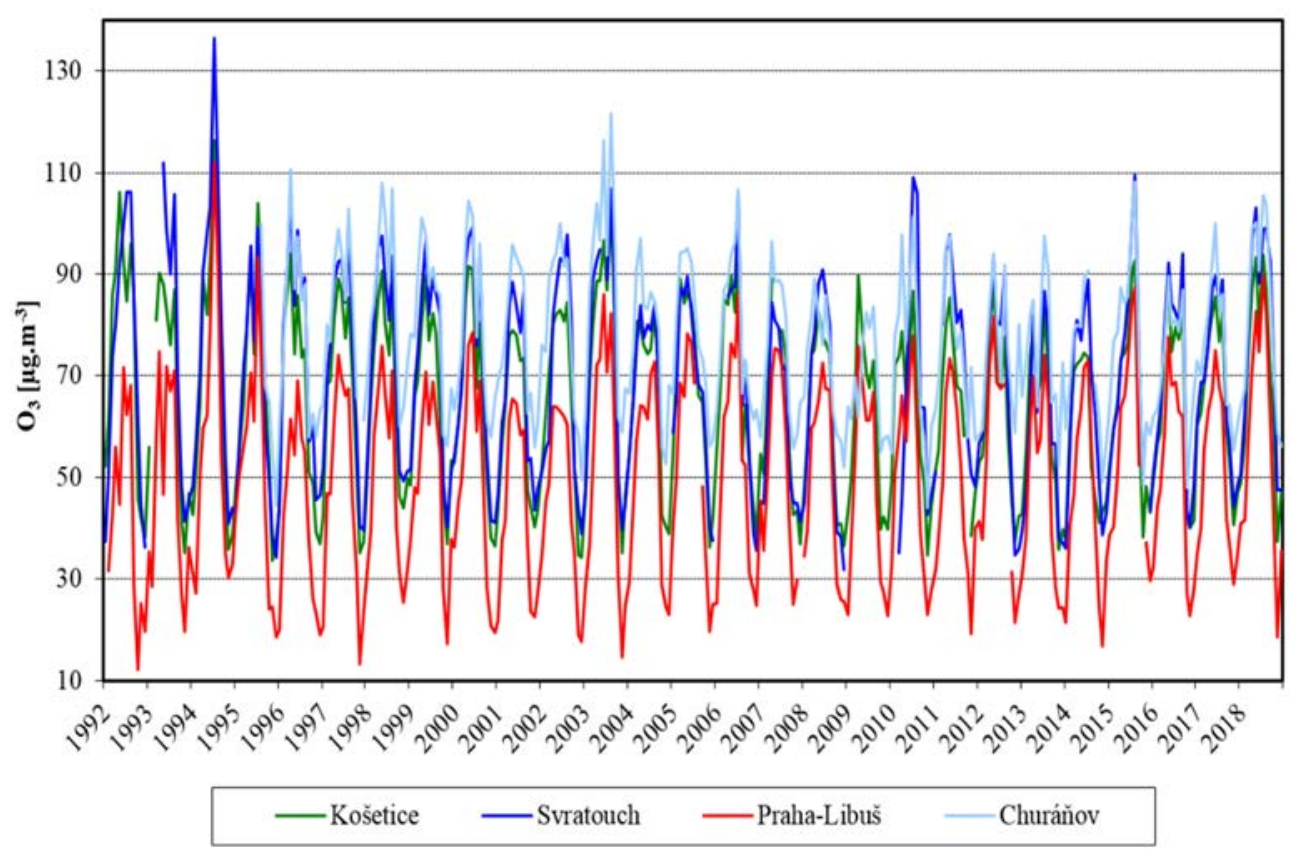

Figure 4: Monthly mean tropospheric ozone concentrations at stations Košetice, Svratouch, Praha-Libuš, Churáňov. 
Fig. 5 clearly shows the diurnal variation of tropospheric ozone concentrations with a minimum at around 6 am and a maximum around $2 \mathrm{pm}$. The diurnal variation at the mountain station is less significant; mean annual concentrations in the nigh time are about $75 \mu \mathrm{g} . \mathrm{m}^{-3}$. The more marked daily variation at the Košetice observatory than at Svratouch is clearly influenced by the lower elevation. The difference is particularly noticeable at night, when the Košetice values fall to an average of $10 \mu \mathrm{g} . \mathrm{m}^{-3}$ less than in Svratouch, while during the day the average concentrations are equal. At Prague suburb, the daily variation in more significant, the concentrations are lower by $10 \mu \mathrm{g} . \mathrm{m}^{-3}$ during the daylight and by $20 \mu \mathrm{g} . \mathrm{m}^{-3}$ in the night in comparison with background level [13].

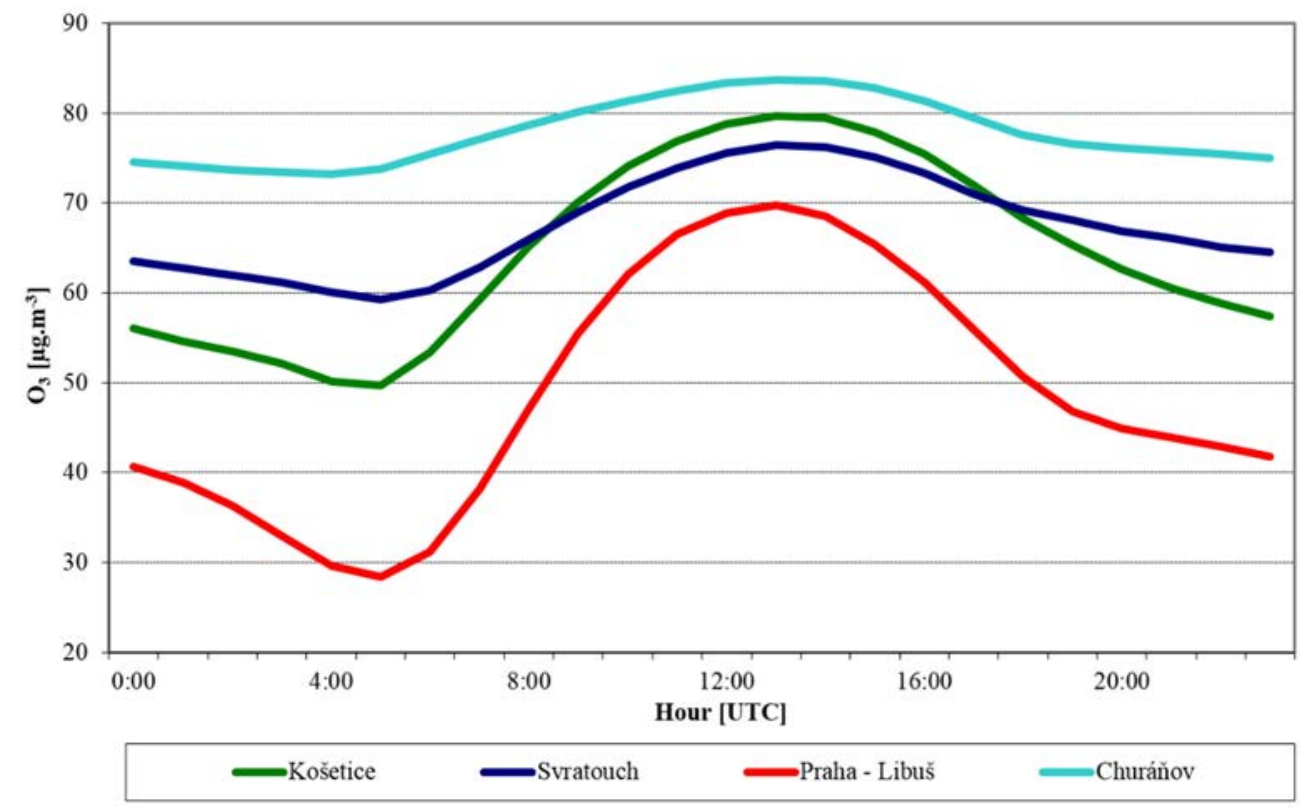

Figure 5: Diurnal variation of tropospheric ozone concentrations at stations Košetice, Svratouch, Praha-Libuš and Churáňov.

\section{CRITICAL LEVELS}

To assess the effects of tropospheric ozone on human health and on vegetation, international and national bodies have gradually introduced a whole system of ambient air pollution limits or critical values during the period under review. In this study, a comparison with current Czech and European ambient pollution limits is used. Target value of tropospheric ozone for protection of human health is exceeded when 8-hour running mean is higher than $120 \mu \mathrm{g} . \mathrm{m}^{-3} 25$ times in average for 3 years. The alert threshold for protection of human health is exceeded when the concentration is at least once per day higher than $180 \mu \mathrm{g} . \mathrm{m}^{-3}$. The limit for protection of ecosystems and vegetation is based on AOT40 index. AOT40 is the sum of differences between the hourly concentration higher than $80 \mu \mathrm{g} \cdot \mathrm{m}^{-3}(=40 \mathrm{ppb})$ and the value $80 \mu \mathrm{g} . \mathrm{m}^{-3}$ in the given period by using only hourly values measured between 8:00 and 20:00 CET. The target value is surpassed when the AOT40 index, calculated between May and July is higher than $18000 \mu \mathrm{g} \cdot \mathrm{m}^{-3} \cdot \mathrm{h}$ in average for 5 years [14]. 
The target limit for human health protection was exceeded at all selected stations almost during the whole period 1993-2005, only at suburb station Prague-Libuš the three-year mean values varied round the target limit in the period 1998-2002 (Fig. 6). Generally, significant drop was found analyzing the whole period at all types of stations. The year 2003 brought the hot summer comparable with early nineties. Although the emissions of ozone precursors declined in the Central Europe, the number of days in which the limit was exceeded in 2003 reached the level of the beginning of the nineties. In the period 2006-2018, significant drop of high ozone episodes continued. The three-year mean fluctuated around the target limit at all stations. The summer 2018 was ones of the hottest in the history of climatological measurement in the Czech Republic and the number of high ozone episodes increased again.

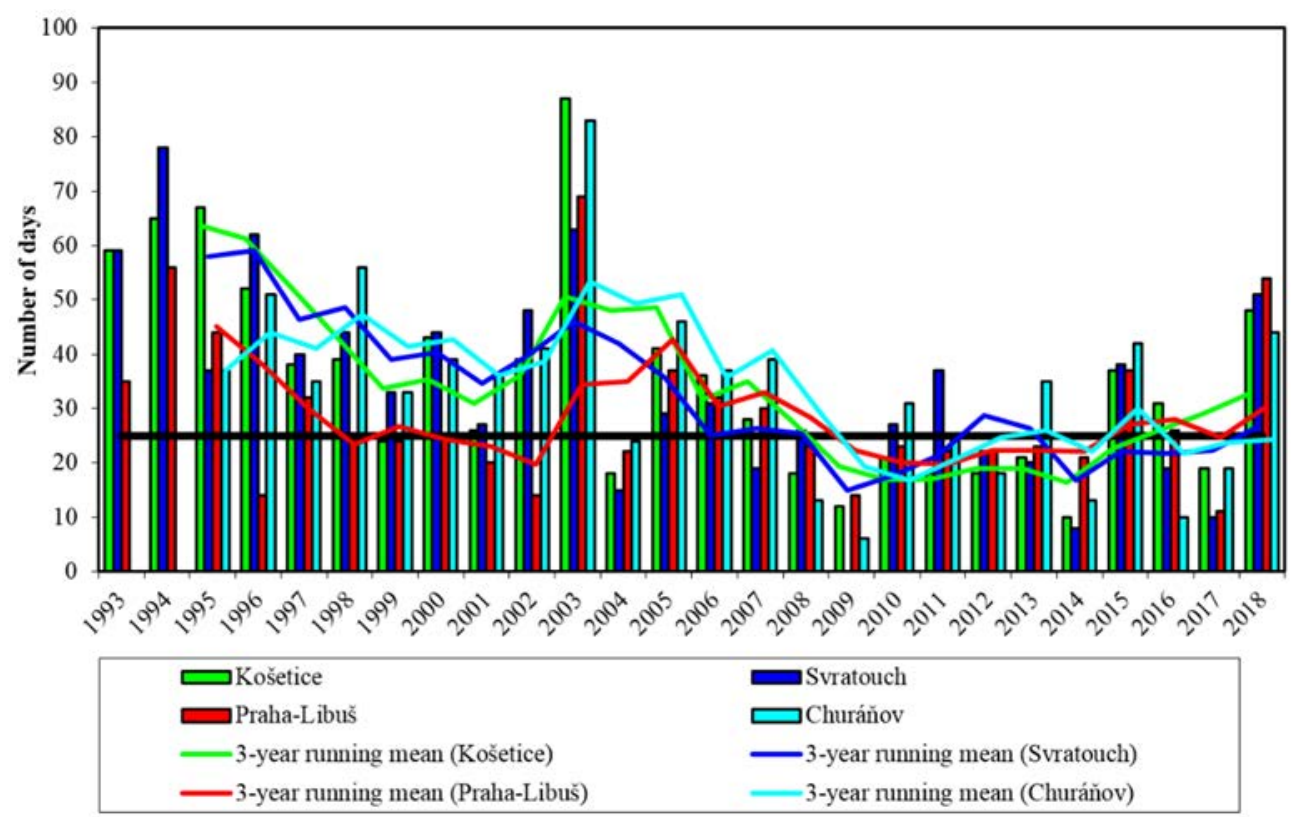

Figure 6: Number of days with the ambient air pollution limit exceedances (sliding 8-hour average higher than $120 \mu \mathrm{g} \cdot \mathrm{m}^{-3}$ ).

In the EMEP domain, the magnitude of high ozone episodes has decreased by about $10 \%$ between 1990 and 2012, resulting in reductions of 20 to $50 \%$ of the number of days exceeding the European long term objective. It should be noted however that such thresholds are still exceeded at a majority of stations, thereby demonstrating both the efficiency of control measures undertaken over the past 20 years, and the need for further action.

Fig. 7 shows very significant drop of high ozone episodes, when the alert threshold $\left(180 \mu \mathrm{g} . \mathrm{m}^{-3}\right)$ was exceeded. Such episodes were quite frequent in the very beginning of the data series (first half of the nineties). Generally, the episodes were recorded more often at the suburban station. By far the highest amount of the episodes with alert threshold exceedances was recorded in the year 1994. The summer of 1994 was extremely warm and, at the same time, the emissions of ozone precursors were still higher than in the rest of the period under review. After 2000, the episodes of alert threshold exceedances occurred very rarely, namely in the years with very hot summers $(2003,2015,2018)$. 


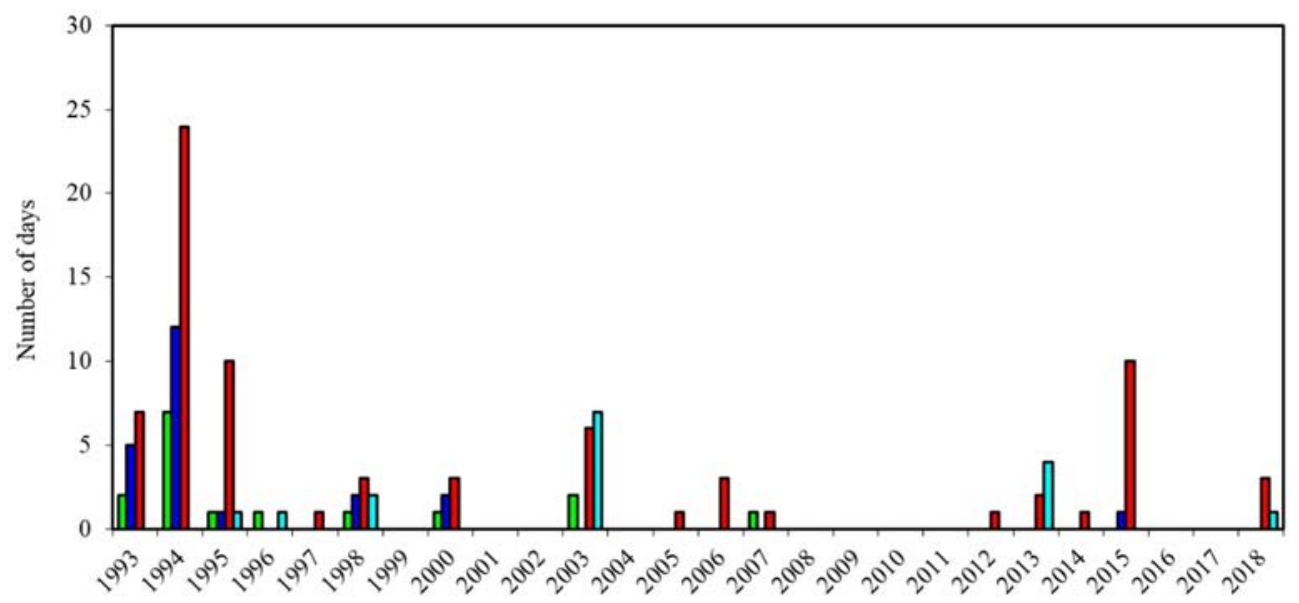

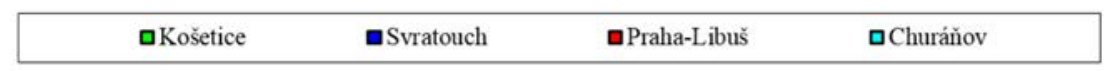

Figure 7: Number of days of the ozone alert threshold exceedance $\left(180 \mu \mathrm{g} \cdot \mathrm{m}^{-3}\right)$.

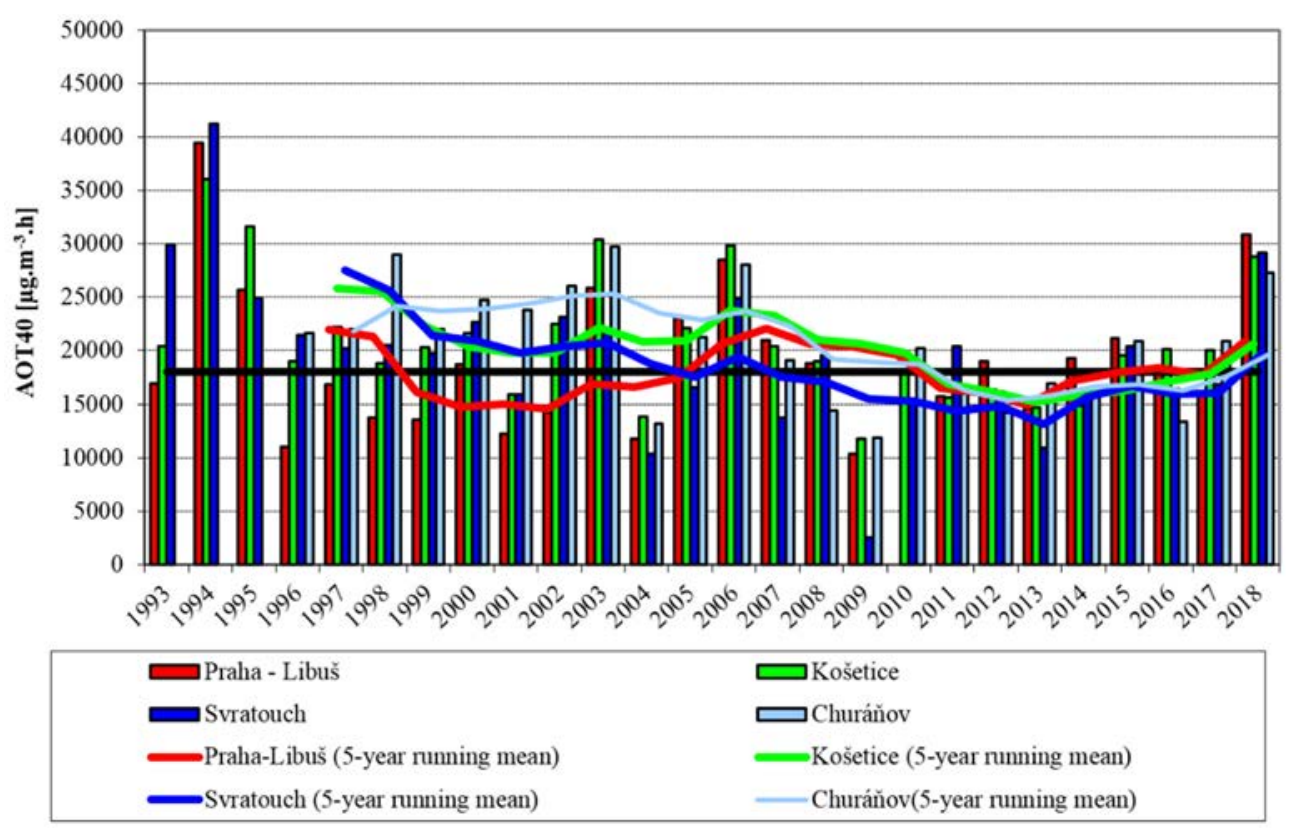

Figure 8: Trend of AOT40 index.

The evaluation of the ozone impacts on vegetation implies that, not only in rural areas, but practically throughout the Czech Republic, critical levels were significantly surpassed in the nineties (Fig. 8). In 1994 the limit was exceeded twice at both background stations. In the second half of the nineties, the values dropped significantly at all stations. The values at 
suburb station Praha-Libuš declined under the target level. The warmer period 2003-2006 brought short-term increase of AOT40 index above the target limit. In the last decade, AOT index varied round the requested level round $18,000 \mu \mathrm{g} \cdot \mathrm{m}^{-3} . \mathrm{h}$. In the very hot summer 2018 the values exceeded the limit significantly.

\section{CONCLUSIONS}

The emissions of tropospheric ozone precursors dropped significantly both in the Czech Republic and in whole the EU. NOx emissions dropped by $80 \%$ in the period 1990-2016 and by $55 \%$ after 2000 in the Czech Republic. The figures for VOCs were $63 \%$ in the period $1990-2016$ and $30 \%$ after 2000 .

Slightly decreasing trend was found in mean annual concentrations at mountain and background level of the Czech Republic in the whole period under review and also in the first part of the period (1993-2005). After 2006 no trend was found. Warm period displays similar patterns as whole year. On contrary, no trend was found in the whole period at background stations and mountain site in the cold period. Suburban level is characterized by slightly increasing trend. The difference between mean annual concentrations at background and suburban stations was smaller during the period under review.

Tropospheric ozone concentrations at the Czech stations have a marked annual variation with maxima at the end of spring. In June and sometimes also in July there is a decrease caused by the onset of the so-called "continental monsoon", which brings increased cloud cover and a drop in solar radiation. We then register a second maximum in July and August (especially in very hot summers). Concentrations at mountain station are higher all year round.

Diurnal variation of tropospheric ozone concentrations is characterized by a minimum at around 6 am and a maximum around $2 \mathrm{pm}$. At suburb station, the diurnal variation in more significant.

The number of episodes with target value for human health exceedances dropped significantly during the period under review, but annual target values surpassed the limit almost in the whole period 1993-2005. Meteorological conditions for the tropospheric ozone creation were favourable in the first half of the nineties, when the majority of episodes were registered. In the period 2006-2018, the three-year mean fluctuated around the target limit at all stations.

Very significant drop of the episodes with alert threshold exceedances was found. The highest amount of the episodes with alert threshold exceedances was recorded in the first half of the nineties, especially in 1994.

Assessment of the ozone impacts on vegetation, using the AOT40 index, suggests that critical level was exceeded for long periods not only in the background areas but almost over the whole Czech Republic; this causes damage to forest ecosystems and farm crops. In the last decade, the values varied round the requested level round $18,000 \mu \mathrm{g} \cdot \mathrm{m}^{-3} . \mathrm{h}$. In the very hot summer 2018 the values exceeded the limit significantly.

In the end of the second decade of the new millennium, tropospheric ozone remains one of the most serious environmental problems of the Central European region; however certain prognoses from the beginning of the nineties, which predicted further continuous growth in tropospheric ozone concentrations in next decades, have not been fulfilled.

\section{ACKNOWLEDGEMENTS}

The research leading to these results has received funding from the project for support of national research infrastructure ACTRIS - participation of the Czech Republic (ACTRIS-CZ - LM2015037) - Ministry of Education, Youth and Sports of the Czech Republic. 
The research leading to these results has received funding from the ACTRIS-2 Integrating Activities (IA), European Union's Horizon 2020 research and innovation programme (grant agreement No 654109).

\section{REFERENCES}

[1] Seinfeld, J.H. \& Pandis, S.N., Atmospheric Chemistry and Physics: From Air Pollution to Climate Change, John Wiley \& Sons: New York, 2006.

[2] Sillman, S., Logan, J.A. \& Wofsy, S.C., 1990. The sensitivity of ozone to nitrogen oxides and hydrocarbons in regional ozone episodes. Journal of Geophysical Research: Atmospheres, 9, pp. 1837-1851, 1990.

[3] Fiala, J. \& Závodský, D., Compendium of air quality protection. Part 2. Chemical aspects of polluted air - tropospheric ozone. Appendix to the Journal Ochrana ovzduší (Air Quality Protection), 2002.

[4] Moldanová, J., Gas-phase chemistry. Atmosphere and Climate. Topic Problems of Ambient Air Protection, M. Braniš \& I. Hůnová, eds, Karolinum: Prague, 2009.

[5] Colbeck, I. \& Mackenzie, A.R., Air Pollution by Photochemical Oxidants. Air Quality Monographs, Vol. 1, Elsevier: Amsterdam, 1994.

[6] Brookes, D. et al., Air Pollution in the UK 2012. Department for Environment, Food and Rural Affairs: London, 2013. http://uk-air.defra.gov.uk/library/annualreport/ viewonline?year=2012_issue_1.

[7] EEA, European Union emission inventory report 1990-2016 under the UNECE convention on long-range transboundary air pollution (LRTAP). EA Report No. 6/2018, 2018. DOI: $10.2800 / 571876$.

[8] EEA, Air quality in Europe - 2013 report. EEA technical report 9/2013. EEA: Copenhagen, 2013. www.eea.europa.eu/publications/air-quality-in-europe-2013.

[9] Air Quality in the Czech Republic 1994-2018, ČHMÚ: Prague.

[10] Salmi, T., Anttila, P., Maattaa, A. \& Ruoho-Airola, T., Detecting trends of annual values of atmospheric pollutants by Mann-Kendall test and Sen's slope estimates. Finnish Meteorological Institute, 2002.

[11] Ozone Measurements 1990-2017, NILU: Kjeller.

[12] Air pollution trends in the EMEP region between 1990 and 2012. Joint Report of : EMEP Task Force on Measurements and Modelling (TFMM), Chemical Coordinating Centre (CCC), Meteorological Synthesizing Centre-East (MSC-E), Meteorological Synthesizing Centre-West (MSC-W). EMEP/CCC Report 1/2016.

[13] Váňa, M. \& Pekárek, J., Long-term trends of surface ozone trends in the Czech Republic. Košetice Observatory - 25 years, ČHMÚ: Prague, 2013.

[14] EC, Directive 2008/50/EC of the European Parliament and of the Council of 21 May 2008 on ambient air quality and cleaner air for Europe, 2008. http://eurlex.europa.eu/LexUriServ/LexUriServ.do?uri=OJ:L:2008:152:0001:0044:C S:PDF. 